\title{
ANATOMICAL ASPECTS OF THE STEM AND LEAF OF MENTHA $x$ PIPERITA L. (LAMIACEAE)
}

\section{Elena Cristina Ciobanu (Țurlea) ${ }^{1}$, Elena Săvulescu ${ }^{1 *}$, Monica Luminița Badea ${ }^{1}$}

\author{
${ }^{1}$ University of Agronomic Sciences and Veterinary Medicine of Bucharest, 59 Marasti Blvd, Bucharest, Romania
}

\section{Current Trends in}

\section{Natural Sciences}

\begin{abstract}
Mentha x piperita (Lamiaceae) has been known since ancient times due to its aromatic and therapeutic properties. The differences in essential oil composition among the members of the genus Mentha offer a diversity of strains with high contents of menthone, menthol, carvone, linalool, or other valued terpenoid components synthesized by the mevalonic acid pathway. The species was analyzed anatomically. As biologic material, stems and leaves have been sampled from crops, during the vegetation period, before blooming. From an anatomical point of view, transverse sections were made through stems and leaves. At the level of the epidermis, both in the stem and in the leaf, the secretory and the tector trichomes were highlighted. The foliar limb is hypostomatic, with stomata in the inferior epidermis, the stomata being of the diacitic type. The mesophilus of the foliar is bifacial, having palisadic tissue with a single layer of cells, located under the superior epidermis and lacunar tissue, located under the inferior epidermis.
\end{abstract}

Keywords: anatomy, leaf, secretory trichomes, stem, stomata

\section{INTRODUCTION}

Mentha $x$ piperita belongs to the Lamiaceae family (Ciocârlan, 2009), has its origins in the Mediteranean region, and is used in the food, cosmetic and pharmaceutical industries (Seif et al. 2019). The Mentha x piperita plants have peltate glandular trichomes (Turner et al., 2000; Svoboda, 2000; Rehman, 2016) and capitate (Svoboda, 2000; Rehman, 2016) functioning for the secretion of the volatile organic compounds. Monoterpenes are the main compounds of the volatile oils of aromatic and medicinal plants, protecting the plant against herbivore animals and pathogen agents (Burzo and Toma, 2012). Peppermint extracts have antiseptic, calming and vasodilation properites, therefore they are used in order to stimulate the nervous system, apetite, digestion, migraines, heart flutter, diarrhea, asthma. Peppermint volatile oil stimulates digestion, cleans the sinuses, is an antiseptic agent, with a strong antibacterial action (Burzo, 2015). According to Cavalcante and al. (2021), organic peppermint leaves were characterized by high carbohydrate content, a high content of total phenolics, total flavonoids, and vitamin C. Because of the antioxidant capacity of these compounds, the use of peppermint leaves as seasonings and spices, can help in the prevention of chronic diseases and in food conservation. Abdelhalim's study (2021) has shown that the administration of an infusion of peppermint can improve the quality of sleep and enhance memory in students. Additionally, peppermint showed a considerable putative beneficial effect on anxiety, stress and insomnia. 


\begin{tabular}{|c|c|}
\hline & \\
\hline $\begin{array}{l}\text { Current Trends in Natural Sciences (on-line) } \\
\text { ISSN: 2284-953X } \\
\text { ISSN-L: 2284-9521 }\end{array}$ & $\begin{array}{l}\text { Current Trends in Natural Sciences (CD-Rom) } \\
\text { ISSN: } 2284-9521 \\
\text { ISSN-L: 2284-9521 }\end{array}$ \\
\hline
\end{tabular}

\section{MATERIALS AND METHODS}

Stems and leaves from the Mentha x piperita genus have been sampled during the vegetation period from crop plants - Ulmeni, Teleorman (Figure 1).

Cross-sections were made in the stems and leaves using the blade and there were clarified with Chloral-hydrate coloured, with the Carmine-Alaunate and Iodine Green (Morlova et al.,1966). The anatomical structures were analysed using the optical microscope Leica DM1000 LED, Leica DFC295 video camera, the Stereomicroscope Leica S8 APO, belonging to the Laboratory of Microscopy and Plant Anatomy of the University of Agronomic Sciences and Veterinary Medicine of Bucharest.

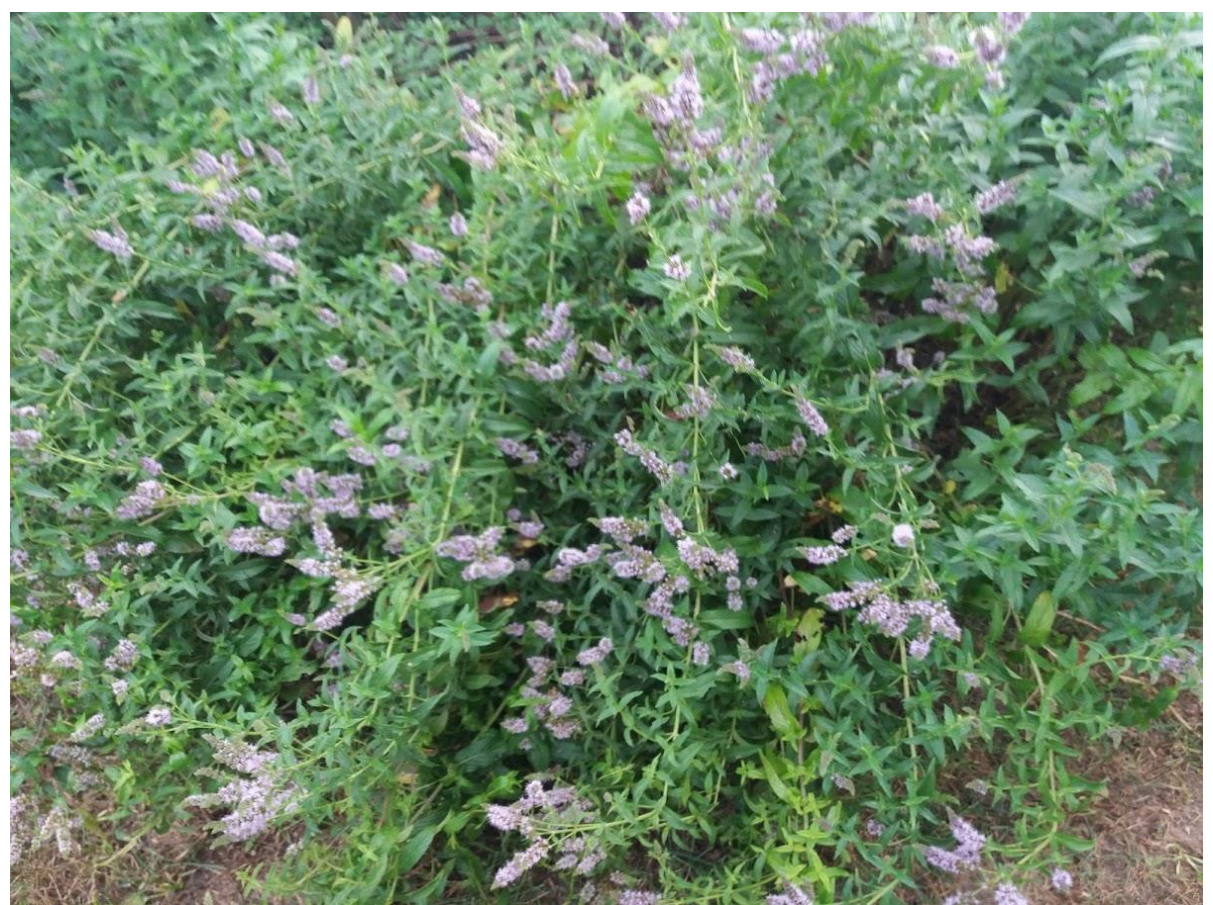

Figure 1. Mentha x piperita L. - Crop

Ulmeni (Teleorman)

\section{RESULTS AND DISCUSSIONS}

\section{Stem anatomy}

The results are similar to the data in the speciality literature (Metcalfe, C.R. and Chalk, L. 1983, Toma and Rugină, 1998, Garner, C., 2017). In the cross-section, the stem is square-shaped, with protruding ribs (Figure 2).

From outside-in, the epidermis, cortex and central cylinder can be observed (Figure 3). The epidermis is formed from a single row of cells, having the external walls covered in a striate cuticle. Inside the epidermis, from place to place, stomata and tector and secretory hairs have been noticed, having a structure similar to plants in the Lamiaceae family (Toma and Rugină 1998; Metcalfe and Chalk, 1983; Andrei, 1978). The secretory hairs are unicellular and also pluricellular, having 4-8 cells in the secretory gland. The cortex is formed of angular cholenchyma bundles, in the 4 ribs, and for the remaining structure, of chlorenchyma strands. The endodermis is of primary type. 


\begin{tabular}{|c|c|}
\hline \multicolumn{2}{|c|}{$\begin{array}{c}\text { Current Trends in Natural Sciences } \\
\text { Vol. 10, Issue 19, pp. 447-452, } 2021 \\
\text { https://doi.org/10.47068/ctns.2021.v10i19.059 }\end{array}$} \\
\hline $\begin{array}{l}\text { Current Trends in Natural Sciences (on-line) } \\
\text { ISSN: 2284-953X } \\
\text { ISSN-L: 2284-9521 }\end{array}$ & $\begin{array}{r}\text { Current Trends in Natural Sciences (CD-Rom) } \\
\text { ISSN: } 2284-9521 \\
\text { ISSN-L: } 2284-9521\end{array}$ \\
\hline
\end{tabular}

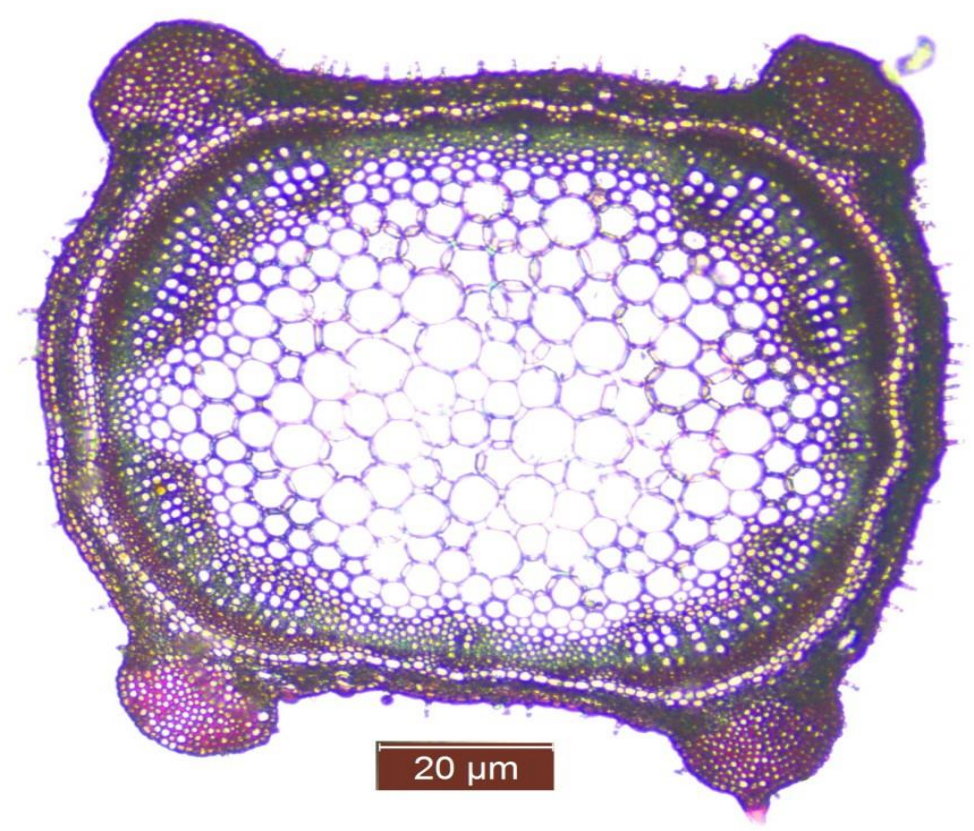

Figure 2. Cross-section of the Mentha $x$ piperita stem $0 b .4 x$

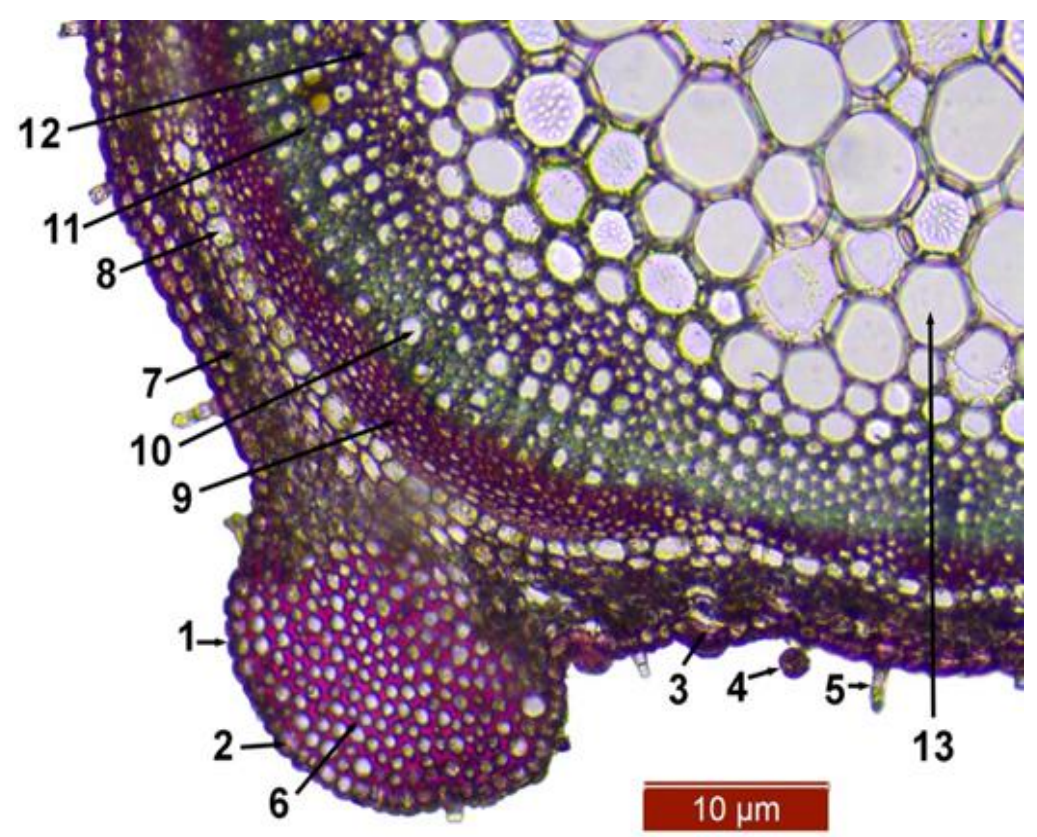

Figure 3. Cross-section of the Mentha $x$ piperita stem, lense $10 x$, detail: 1 -cuticule; 2 -epidermis; 3 - stomata; 4 - secretory hair; 5 - tector hair; 6 -angular collenchyma; 7 -chlorenchyma; 8 endodermis; 9 -phloem; 10 -xylem; 11 -medullary ray; 12 -primary xylem; 13 -pith.

The vascular bundles are collateral, many of them of secundary origin, being much larger in the ribs.The phloem ring is situated on the outside, consisting of liberian vessels, annexins and cellulosic parenchyma. The xylem ring is situated on the inside and is thicker, consisting of wooden vessels, wooden parenchyma and wood fibers. The wooden vessels are separated by sclerified 


\begin{tabular}{|c|c|}
\hline & $\begin{array}{c}\text { Current Trends in Natural Sciences } \\
\text { Vol. 10, Issue 19, pp. 447-452, } 2021 \\
\text { https://doi.org/10.47068/ctns.2021.v10i19.059 }\end{array}$ \\
\hline $\begin{array}{l}\text { Current Trends in Natural Sciences (on-line) } \\
\text { ISSN: 2284-953X } \\
\text { ISSN-L: 2284-9521 }\end{array}$ & $\begin{array}{l}\text { Current Trends in Natural Sciences (CD-Rom) } \\
\text { ISSN: } 2284-9521 \\
\text { ISSN-L: 2284-9521 }\end{array}$ \\
\hline
\end{tabular}

medullary rays. The primary origin xylem is reduced, and the wooden vessels are separated by parenchymatic medullary rays. The pith is parenchymatic, of cellulose structure, where the cells in the middle part are in the process of dislocation. In the pith cells, there were noticed starch granules and calcium oxalate crystals.

\section{Leaf anatomy}

The epidermis as seen from the front consists of cells with robust wavy walls. From place to place, octocellular secretory hairs can be noticed, and also tector hairs (Figure 4).

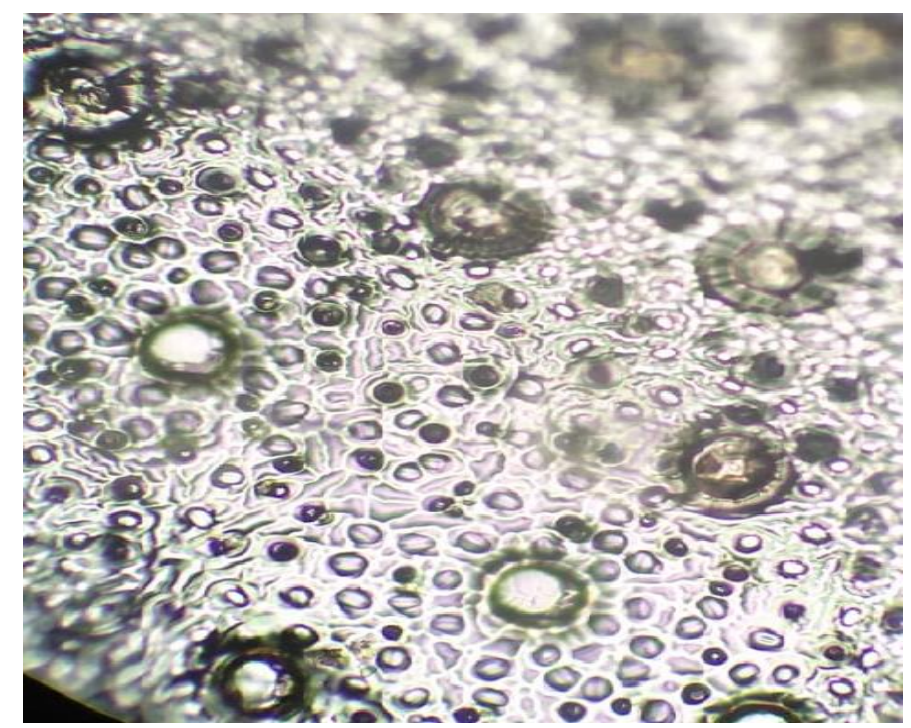

Figure 4. Secretory and tector hairs in the lower epidermis Mentha $x$ piperita, ob. $10 x$

The leaf is hyposomatic, having stomata only in the lower epidermis, of the diacitic type, with two annex cells located perpendicularly on the somatic cells (Figure 5, 6).

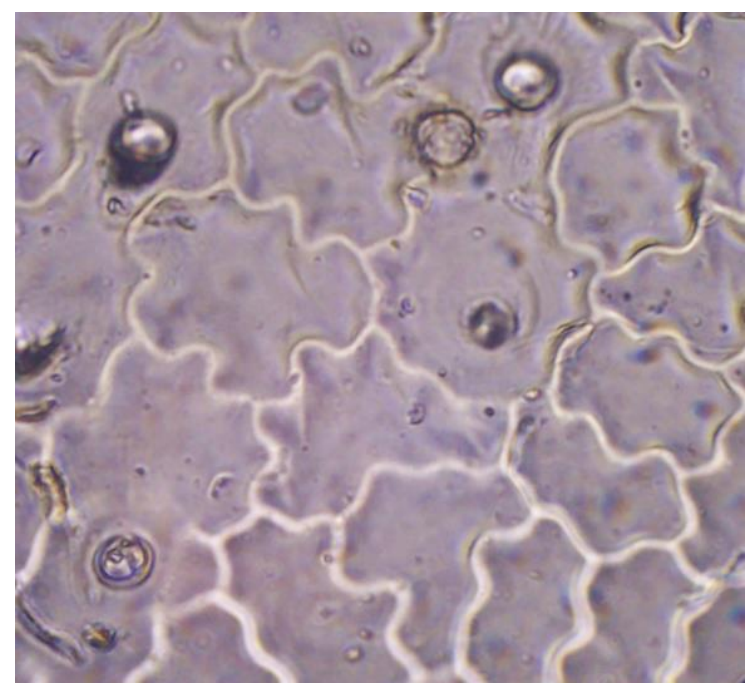

Figure 5. The upper epidermis as seen from the front Mentha $x$ piperita $o b .20 x$ upper epidermis (adaxial epidermis)

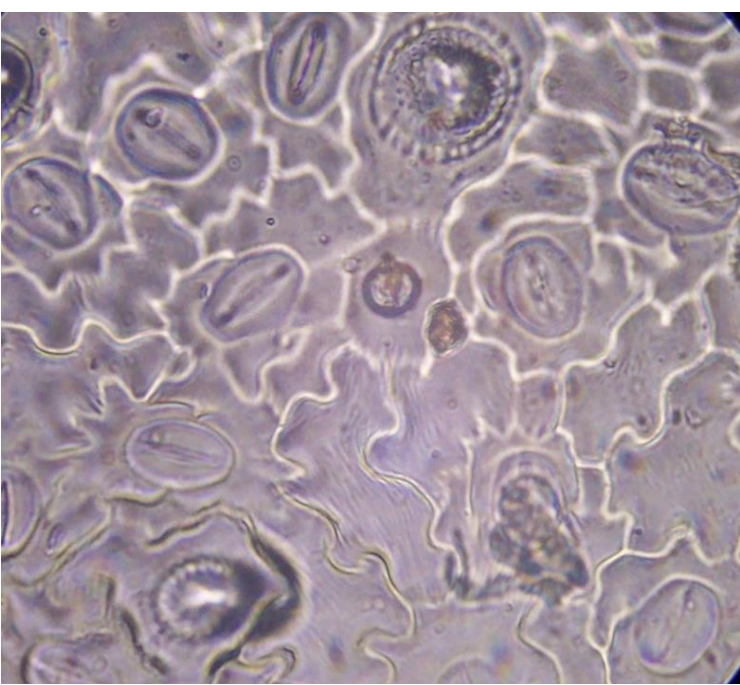

Figure 6. The lower epidermis as seen from the front Mentha $x$ piperita, ob.20 x-lower epidermis (abaxial epidermis) 


\section{Current Trends in Natural Sciences}

Vol. 10, Issue 19, pp. 447-452, 2021

https://doi.org/10.47068/ctns.2021.v10i19.059

Current Trends in Natural Sciences (on-line)

ISSN: 2284-953X

Current Trends in Natural Sciences (CD-Rom)

ISSN: 2284-9521

ISSN-L: 2284-9521

ISSN-L: 2284-9521

In cross-section through the lamina, the middle string is highly protruding on the lower side, with a hypodermic collenchyma and a collateral vascular bundle located in the center, with a xylem on the outside and phloem on the inside (Figure 7).

In both leaf epidermis, secretory and tector hairs are present. The secretory hairs are unicellular or pluricellular and are more frequent in the lower epidermis, having the same structure as those present in the stem.

The mesophyll is of bifacial type, separated in palisade tissue and spongy tissue. The palisade tissue is located under the upper epidermis consisting of a single layer of elongated cells, rich in chloroplasts.

The spongy tissue, located under the lower epidermis, consists of 3-4 rows of isodiametric cells, having thin walls with intercellular spaces and a lower content of chloroplasts.

In the mesophyll there were observed vascular collateral bundles and mineral crystals.

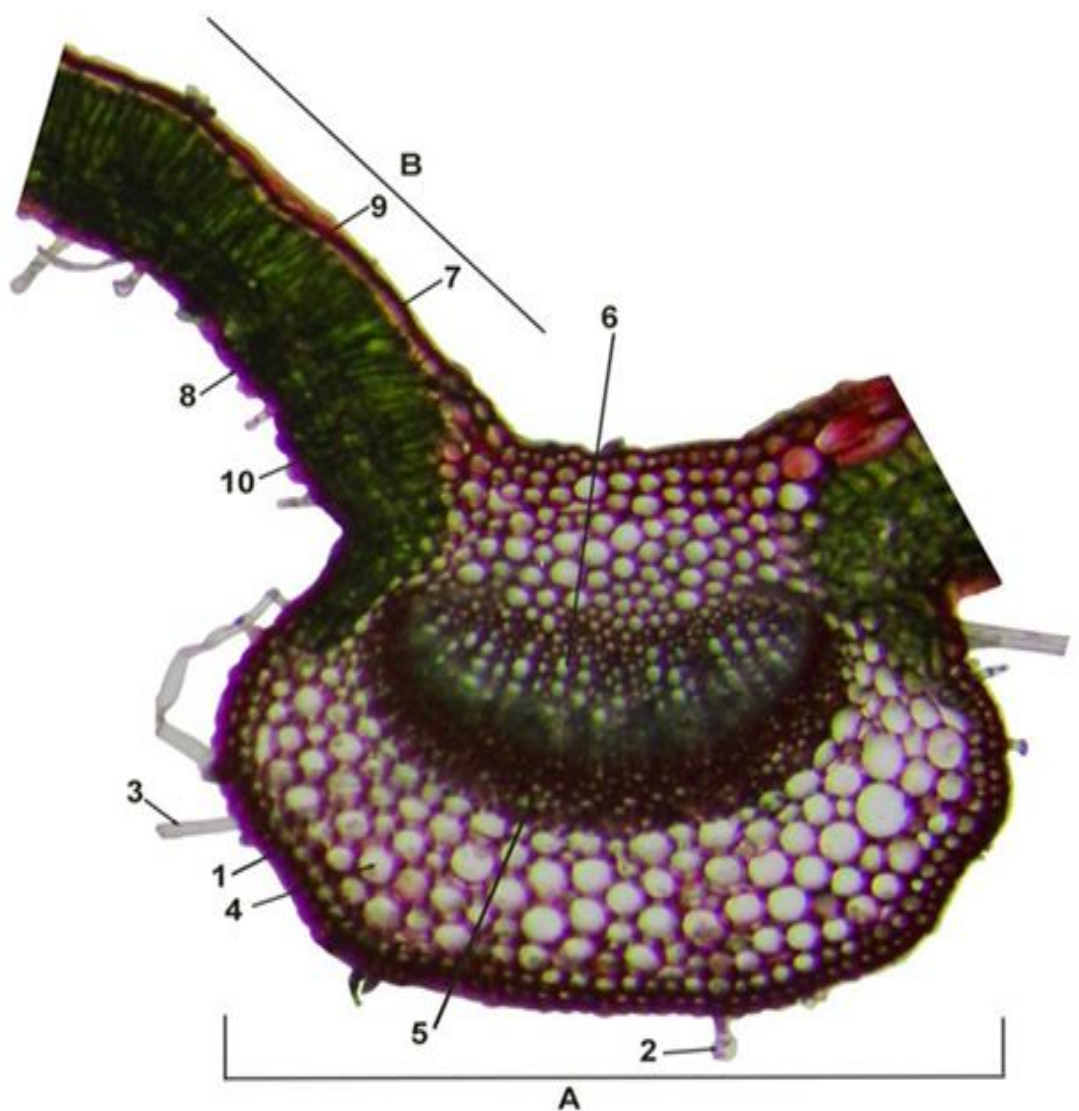

Figure 7. Cross-section of the Mentha $x$ piperita lamina, ob . 10x

A - middle string: $B$ - lamina; 1 -epidermis; 2 - secretory hair; 3 -tector hair; 4 collenchyma; 5 -phloem; 6 -xylem; 7 -upper epidermis;

8 -lower epidermis; 9 -palisade tissue; 10 -wooden tissue 


\section{Current Trends in Natural Sciences}

Vol. 10, Issue 19, pp. 447-452, 2021

https://doi.org/10.47068/ctns.2021.v10i19.059

Current Trends in Natural Sciences (on-line)

ISSN: 2284-953X

Current Trends in Natural Sciences (CD-Rom)

ISSN: 2284-9521

ISSN-L: 2284-9521

ISSN-L: $2284-9521$

\section{CONCLUSIONS}

At stem level, the epidermis has stomata and secretory and tector hairs. Secretory hairs are unicellular and pluricellular, with globular secretory gland. Vascular tissues in the stem are collateral, of secondary origin, being larger in the ribs. The leaf is hypostomatic, the stomata being of diacitic type. Secretory and tector hairs are present at the upper and lower epidermis level.

The secretory hairs are unicellular or pluricellular, usually octocellular, being frequent in the lower epidermis. The leaflet mesophyll is of bifacial type, differentiated in palisadic tissue, under the upper epidermis, and spongy tissue, located under the lower epidermis.

\section{REFERENCES}

Abdelhalim, A.R. (2021). The effect of Mentha piperita L. on the mental health issues of university students: A pilot study, Journal of Pharmacy \& Pharmacognosy Research, 9 (1), 49-57, ISSN 0719-4250, http://jppres.com/jppres.

Andrei, M. (1978). Anatomia plantelor. [Anatomy of plants ]. Editura Didactică și Pedagogică, București, p. 170.

Burzo, I., Toma, C. (2012). Țesuturile secretoare și substanțele volatile din plante. [ Secretory tissues and volatile substances from plants]. Editura Universității „,Alexandru I. Cuza”, Iași, ISBN: 978-703-762-6, p.23-25.

Burzo, I. (2015). Compoziția plantelor medicinale și alimentare din flora spontană și cultivată. [Composition of medicinal and edible plants from the spontaneous and cultivated flora]. Editura Elisavaros, București, ISBN 978 606-8147-55-0, p.310.

Cavalcante, M.B.R, Barros de Moura, A.J., Mota Araujo, M.A., Moreira-Araujo, R.S.R. (2021). Bioacessibility of phenolic compounds and antioxidant capacity in organic peppermint leaves, Rev. Chil. nutr. vol. 48, nr.2, Santiago abr. 2021, ISSN 0717-7518, http://dx.doi.org/10.4067/S0717-75182021000200157.

Ciocârlan, V. (2009). Flora Ilustrată a României (Pteridophyta et Spermatophyta). [The illustrated flora of Romania (Pteridophyta et Spermatophyta)], Editura Ceres, București, 675-678.

Garner, C. (2017). "Hallmark Features of Stem Anatomy in the Family Lamiaceae", University of South Carolina, Scholar Commons, 30.

Metcalfe, C.R. and Chalk, L. (1983). Anatomy of the dicotyledones, 2nd. Vol. II. Clarendon press. Oxford.

Morlova, I., Chirilă, C., Ursu, T., Baciu, E., Ciocîrlan, V., Cosmin, S., Oprea, C., Turcu, Ghe, Dobre, F., Ungureanu, L. (1966). Botanică. Lucrări practice. [Botanical. Practical work]. Editura Didactică și Pedagogică, București.

Rehman, R.,Hanif1, M.A., Mushtaq, Z., Mochona, B., and Qi, X., (2016). Biosynthetic Factories of Essential Oils: The Aromatic Plants, Nat Prod Chem Res, 4:4. http://dx.doi.org/10.4172/2329-6836.1000227

Seif Sahandi, M., Mehrafarin, A., Khalighi Sigaroodi, F., Sharifi, M. and Naghdi Badi, H. (2019). Review on Anatomical, Phytochemical and Pharmacological Properties of Peppermint (Mentha piperita L.), Journal of medicinal plants, volume 18, nr.69, 16-33.

Toma, C., Rugină, R. (1998). Anatomia plantelor medicinale. Atlas. [Anatomy of medicinal plants. Atlas], Editura Academiei Române, București, 149-172.

Svoboda, K. P. and Svoboda T. G. (2000). Secretory structures of aromatic and medicinal plants, ISBN 0-9538461-0-5, p.42.

Turner, G.W., Rshenzon, J., Croteau, R.B. (2000). Distribution of peltate glandular trichomes on developing leaves of peppermint, Plant Physiol, 2000, 124 (2): 655-664, doi: 10.1104/pp.124.2.655. 